\title{
Implementasi Peraturan Daerah Nomor 13 Tahun 2016 Tentang Ketertiban Umum dan Ketentraman Masyarakat dalam Mengatasi Tindakan Perusakan Terhadap Fasilitas Umum di Kota Watampone
}

\author{
Aji Purnomo \\ Institut Agama Islam Negeri (IAIN) Bone \\ ajipurnomo98@gmail.com
}

\begin{abstract}
Abstrak
Tujuan penelitian ini adalah penulis ingin mengetahui peran pemerintah dalam menjaga dan merawat fasilitas umum di Kota Watampone agar tercipta kenyamanan saat menggunakan fasilitas umum. Selain itu penulis juga ingin mengetahui upaya pemerintah dalam menangani kasus perusakan terhadap fasilitas umum yang cukup meresahkan masyarakat serta kendala yang dihadapi oleh pemerintah dalam penegakan Peraturan Daerah tersebut. Penulis menggunakan pendekatan normatif-empiris dalam penelitian ini Kemudian teknik pengumpulan data yang digunakan adalah wawancara, observasi dan catatan lapangan serta untuk teknik analisis data yang penulis gunakan adalah teknik analisis data secara kualitatif. Berdasarkan hasil penelitian, penulis dapat menyimpulkan. Peran pemerintah seharusnya memberikan sarana operasional kepada Satuan Polisi Pamong Praja (SATPOL PP) guna mempermudah pelaksanaan dan penegakan perda khususnya mengenai tindakan perusakan. Peran masyarakat juga dibutuhkan agar dapat bersinergi dengan pemerintah dan pro-aktif melaporkan setiap tindakan perusakan fasilitas umum yang dilakukan oleh oknum yang tidak bertanggung jawab.
\end{abstract}

Kata Kunci : Peraturan Daerah Nomor 13 Tahun 2016, Ketertiban Umum dan Ketentraman Masyarakat dan Perusakan Terhadap Fasilitas Umum di Kota Watampone

\section{PENDAHULUAN}

Sejak awal kemerdekaan Indonesia, pembangunan terus dilakukan oleh pemerintah baik untuk memenuhi kebutuhan masyarakat maupun pembangunan untuk melayani masyarakat. Pemerintah terus melakukan pembangunan dari masa ke masa mulai dari orde lama hingga masa reformasi baik di bidang sosial, ekonomi hingga sarana dan prasarana umum lainnya. Pelaksanaan pembangunan nasional yang bertujuan untuk tercapainya masyarakat yang adil dan makmur adalah pembangunan 
nasional yang menciptakan kemajuan-kemajuan diberbagai bidang. ${ }^{1}$

Pada dasarnya, negara hukum kesejahteraan yang sering juga disebut dengan negara hukum materil atau negara kesejahteraan (welfare state) adalah negara dimana pemerintah tidak hanya bertanggung jawab terhadap pemeliharaan ketertiban dan ketentraman masyarakat, akan tetapi juga bertanggung jawab atas kesejahteraan masyarakat dan tidak satupun aspek kehidupan masyarakat yang lepas dari campur tangan pemerintah (from the cradle to the grave). Hubungan antara negara dan hukum di satu sisi lainnya melahirkan keterikatan hukum pada negara. ${ }^{2}$

Peran hukum dalam pembangunan negara diwujudkan secara nyata melalui dua aspek utama. Pada langkah awal hukum menata kehidupan negara dan meletakkan dasar yuridis bagi perencanaan dan pelaksanaan pembangunan nasional, satu diantaranya adalah pembangunan ekonomi. Langkah selanjutnya adalah pembentukan hukum dan penerapannya. Hukum menciptakan kondisi-kondisi yang memungkinkan pelaksanaan pembangunan dan mengamankan hasilnya.

Dalam literatur, sejumlah pakar telah merumuskan fungsi negara antara lain, Adam Smith, Wolfgang Friedman dan L.A. Geelhoed. Menurut Adam Smith, fungsi negara meliputi, menjaga keamanan dan ketertiban sesuai dengan batas wewenang yang ditetapkan negara itu sendiri, kolektifitas (security and order), menegakkan keadilan (justice enforcement) dan membangun sarana dan prasarana publik (public infrastructure development).

Rasyid membagi fungsi pemerintahan menjadi empat bagian, yaitu pelayanan (public service), pembangunan (development), pemberdayaan (empowering), dan

\footnotetext{
1 Asteryna Anandita, "Pelaksanaan Pembangunan Sarana Prasarana Lingkungan Sebagai Wujud Program Pemberdayaan Masyarakat Di Kelurahan Dinoyo Kota Malang”(Jurnal, Malang) h.2

2 Murtir Jeddawi, Hukum Pemerintahan Daerah (Cet. 1 ; Yogyakarta : UII Press Yogyakarta, 2006) h. 36

Jurnal Al-Dustur; VOLUME 2 NO 1, JUNI 2019
} 
20 | Implementasi Peraturan Daerah Nomor 13 Tahun 2016

pengaturan (regulation). Dengan mengutip Franklin D Rosevelt, Rasyid mengemukakan bahwa untuk mengetahui suatu masyarakat, maka lihatlah pemerintahannya. Artinya, fungsi-fungsi pemerintahan yang dijadikan pada saat tertentu menggambarkan kualitas pemerintahan itu sendiri. Jika pemerintah dapat menjalankan fungsi-fungsinya dengan baik, tugas pokok selanjutnya menurutnya adalah bagaimana pelayanan dapat membuahkan keadilan, pemberdayaan yang membuahkan kemandirian, serta pembangunan yang menciptakan kemakmuran. ${ }^{3}$

Adam Smith berpendapat, berdasarkan sistem kebebasan alamiah, penguasa hanya mempunyai tiga kewajiban, sebagai berikut : (a) penguasa berkewajiban untuk melindungi masyarakat dari tindakan kekerasan dan invasi dari masyarakat bebas lainnya. (b) penguasa berkewajiban melindungi setiap anggota masyarakat dari ketidakadilan atau penindasan yang dilakukan oleh anggota lain dalam masyarakat. (c) penguasa berkewajiban menyediakan sarana dan prasarana umum yang tidak dapat disediakan, dibangun atau dipelihara sendiri oleh anggota masyarakat. ${ }^{4}$

Pemerintah daerah memiliki peran penting selaku wakil pemerintah pusat yang bersentuhan langsung dengan masyarakat. pemerintah daerah berkewajiban untuk membangun fasilitas umum dan ruang publik untuk kepentingan masyarakat. Bagi masyarakat, pemerintah dikatakan berhasil apabila mampu membangun fasilitas umum yang aman dan nyaman. Fasilitas umum perlu mendapatkan perhatian dari segala pihak untuk menjaga dan merawatnya agar masyarakat merasa betah dan nyaman dalam menggunakan fasilitas umum. Pembangunan di daerah menekankan pada kualitas sumber daya lokal, peluang kerja untuk masyarakat, serta inisiatif dan partisipasi serta kemitraan antara unsur yang ada. ${ }^{5}$

3 Muhadam Labolo, Memahami Ilmu Pemerintahan, (t.Cet; ed. 1; Jakarta: PT Raja Grafindo Persada, 2006) h. 23

4 Murtir Jeddawi, Hukum Pemerintahan Daerah h. 37

${ }^{5}$ Asteryna Anandita, “Pelaksanaan Pembangunan Sarana Prasarana (Jurnal, Malang) h.4 Jurnal Al-Dustur; VOLUME 2 NO 1, JUNI 2019 
Pemerintah selaku pihak yang bertanggung jawab dalam hal pembangunan juga mendapatkan beberapa masalah dalam menjalankan pembangunan. Contohnya saja mengenai pembangunan fasilitas umum, pemerintah telah membangun beberapa fasilitas umum guna menunjang kehidupan masyarakat. Namun masih terdapat beberapa oknum yang tidak menjaga dan memelihara fasilitas umum.

Fasilitas umum merupakan sarana yang digunakan oleh seluruh lapisan masyarakat, oleh karena itu diperlukan peran berbagai pihak untuk bersama-sama menjaganya agar tetap aman dan nyaman. Masyarakat perlu menyadari bahwa fasilitas umum adalah milik bersama sehingga masyarakat juga berperan sebagai pengawas terhadap para oknum yang merusak fasilitas umum. Faslitas umum seharusnya dijaga dan dirawat oleh seluruh lapisan masyarakat, namun faktanya beberapa fasilitas umum di wilayah perkotaan tidak dijaga sebagaimana mestinya. Beberapa oknum justru menghancurkan, merusak dan mencorat-coret beberapa fasilitas umum yang ada di wilayah perkotaan.

Tindakan perusakan dan penghancuran terhadap fasilitas umum merupakan bagian dari perilaku vandal. Kata vandal menurut Kamus Besar Bahasa Indonesia (KBBI) adalah seseorang yang memiliki kecenderungan merusak atau menghancurkan. Tindakan perusakan dan penghancuran yang dimaksud adalah tindakan pencacatan, mencorat-coret fasilitas umum menggunakan cat semprot, dan segala bentuk keganasan yang bertujuan untuk merusak dan menghancurkan fasilitas umum dan perlengkapannya. Sedangkan Vandalisme (va.ndal.is.me) perbuatan merusak dan menghancurkan hasil karya seni dan barang berharga lainnya atau bersifat merusak dan menghancurkan secara kasar dan ganas. ${ }^{6}$

Pelaku perusakan atau penghancuran (vandal) mayoritas remaja yang masih

6 Kamus Besar Bahsa Indonesia, (Ed. Ke-3; Cet. 3; Jakarta : PT Penerbitan dan Percetakan Balai Pustaka, 2005) h.1258

Jurnal Al-Dustur; VOLUME 2 NO 1, JUNI 2019 
mencari jati dirinya. Paradigma kenakalan remaja lebih luas cakupannya dan lebih dalam bobot isinya. Kenakalan remaja tersebut meliputi perbuatan-perbuatan yang sering menimbulkan keresahan dilingkungan masyarakat, sekolah maupun keluarga. Beberapa perbuatan yang dilakukan oleh remaja seperti corat-coret tembok pagar yang tidak pada tempatnya. ${ }^{7}$ Disamping itu anak-anak remaja juga melakukan beberapa kejahatan yang lain, seperti : penipuan, penggelapan, gelandangan, pengrusakan dan pemerasan. ${ }^{8}$

Diteliti dalam kenyataan, banyak sekali cara hidup seseorang atau beberapa orang yang menunjukkan adanya perbedaan dengan nilai-nilai atau ukuran-ukuran sosial, misalnya : cara-cara hidup anak delinkwen. Anak remaja yang menjadi delinkwen karena keadaan keluarga, sekolah bahkan karena lingkungan masyarakat pada umumnya mereka suka melakukan perbuatan yang masyarakat dan mengancam ketentramannya termasuk pengrusakan. ${ }^{9}$

Dalam Islam terdapat perbuatan terpuji dan tidak terpuji, perbuatan yang terpuji yang harus diamalkan terdapat dalam Al-qur'an dan hadits Nabi Muhammad SAW tentang hal-hal sebagai perbuatan tercela. Perbuatan terpuji yang dimuat dalam al-qur'an dan hadits diantaranya : tolong-menolong dalam kebaikan, menjaga kesucian diri termasuk kehormatan, menepati janji, adil, shidiq, bersifat ramah dan pemaaf. Sedangkan perbuatan-perbuatan tercela yang dimaksud antara lain : judi, zina, pencurian, perampokan, penganiayaan, pembunuhan dan perbuaatan-perbuatan tercela lain yang merugikan umat manusia, ialah : pengrusakan lingkungan yang berupa tumbuh-tumbuhan, binatang dan bangunan. ${ }^{10}$ Pengerusakan lingkungan dan bangunan

${ }^{7}$ Sudarsono, Kenakalan Remaja (Cet. 5; Jakarta : PT Rineka Cipta, 2008) h. 12

${ }^{8}$ Sudarsono, Etika Islam Tentang Kenakalan Remaja (Cet. IV; Jakarta : PT Rineka Cipta, 2005) h. 7

9 Sudarsono, Etika Islam Tentang Kenakalan Remaja h. 33

10 Sudarsono, Etika Islam Tentang Kenakalan Remaja h. 59 Jurnal Al-Dustur; VOLUME 2 NO 1, JUNI 2019 
termasuk kedalam perbuatan tercela yang merugikan umat manusia. Maka dari itu tindakan pengerusakan dan penghancuran merupakan perbuatan yang tercela.

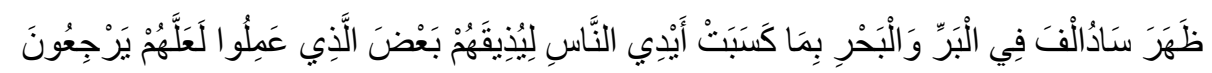

Terjemahan : "Telah nampak kerusakan didarat dan di laut disebabkan karena perbuatan tangan manusia, sehingga akibatnya Allah mencicipkan kepada mereka sebagian dari perbuatan mereka, agar mereka kembali” Q.S Ar-Rum/30:41.11

Sikap kaum musyrikin yang diuraikan ayat tersebut, yang intinya adalah mempersekutukan Allah, dan mengabaikan tuntunan-tuntunan agama, berdampak buruk terhadap diri mereka, masyarakat dan lingkungan. Ini dijelaskan oleh ayat diatas dengan menyatakan : "Telah nampak kerusakan di darat seperti kekeringan, paceklik hilangnya rasa aman dan dilaut seperti ketertenggelaman, kekurangan hasil laut dan sungai, disebabkan karena perbuatan tangan manusia yang durhaka, sehingga akibatnya Allah mencicipkan yakni merasakan sedikit kepada mereka sebagian dari akibat perbuatan dosa dan pelanggaran mereka, agar mereka kembali ke jalan yang benar. $^{12}$

فَأَكْثَرُوا فِيَهَا الْفَسَادَ

Terjemahan : "Lalu mereka berbuat banyak kerusakan dalam negeri itu” Q.S Al-fajr/89 $: 12 .^{13}$

Al-fasad atau kerusakan itu tidak hanya menyentuh sasaran kesewenangan, tetapi juga pelaku kesewenangan. Para pelaku semakin dijungkirbalikkan nilai-nilai luhur karena ingin mempertahankan diri dari kekuasaan, dan ini semakin

\footnotetext{
${ }^{11}$ M. Quraish Shihab, Tafsir Al-Mishbah, (Cet. 4 ; Jakarta : Penerbit Lentera Hati, 2005) h.76

${ }^{12}$ M. Quraish Shihab, Tafsir Al-Mishbah h.76

${ }^{13}$ M. Quraish Shihab, Tafsir Al-Mishbah h.250

Jurnal Al-Dustur; VOLUME 2 NO 1, JUNI 2019
} 
memperkejam penganiayaan yang menimbulkan semakin dalamnya dendam pada anggota masyarakat yang teraniaya sehingga akhirnya meledak. Bila itu terjadi, akan lahir aneka kegiatan yang memporak-porandakan negeri dan nilai-nilai kemanusiaan. Memang, revolusi sosial sering kali menghasilkan pengrusakan dan kekejaman yang berada diluar nilai-nilai kemanusiaan dan yang menghancurkan hasil pembangunan bahkan meruntuhkan peradaban suatu bangsa. Kenyataan sejarah selalu membuktikan hal tersebut. ${ }^{14}$

Berdasarkan pendapat Henri Gregoire yang menggolongkan tindakan perusakan dan penghancuran (vandalisme) sebagai tindakan kejahatan yang kemudian beberapa negara membuat aturan tentang tindakan tersebut seperti Inggris, Australia, dan Singapura. Indonesia adalah negara hukum merupakan salah satu negara yang juga membuat aturan tentang tindakan penghancuran atau pengerusakan barang yaitu dalam Kitab Undang-Undang Hukum Pidana (KUHP) pada bab XXVII tentang menghancurkan atau merusakkan barang pasal 406-412.

\section{Dalam Kitab Undang-Undang Hukum Pidana (KUHP) pasal 408 :} "Barangsiapa dengan sengaja melawan hukum menghancurkan merusakkan atau membikin tak dapat dipakai bangunan-bangunan kereta api trem, telegraf, telepon atau listrik, atau bangunan-bangunan untuk membendung, membagi atau menyalurkan air, saluran gas, air atau saluran yang digunakan untuk keperluan umum, diancam dengan pidana penjara paling lama empat tahun". ${ }^{15}$

Menghancurkan dan merusak barang tertentu yang di terangkan secara khusus dalam pasal ini, diatur dalam 408 KUHP. Adapun unsur-unsur dalam pasal 408 KUHP adalah unsur objektif meliputi menghancurkan dan merusakkan, membuat tidak dapat

\footnotetext{
${ }^{14}$ M. Quraish Shihab, Tafsir Al-Mishbah h.250

15 Ismu Gunadi, Cepat dan Mudah Memahami Hukum Pidana, (Cet. Ke-2 ; Jakarta : PT Fajar Interpratama Mandiri, 2015) h. 339

Jurnal Al-Dustur; VOLUME 2 NO 1, JUNI 2019
} 
dipakai lagi (bangunan, jalan kereta api, jalan term, telepon, listrik, bendungan air,dan pipa gas) yang digunakan untuk kepentingan umum. Unsur subjektif meliputi perbuatan itu dilakukan dengan sengaja dan dengan melawan hukum. ${ }^{16}$

Pada buku ketiga Kitab Undang-Undang Hukum Pidana (KUHP) BAB I tentang pelanggaran keamanan umum bagi orang atau barang juga menjelaskan pula tentang tindakan perusakan terhadap barang yaitu pada pasal 489 ayat (1) yang menyebutkan bahwa "kenakalan terhadap orang atau barang yang dapat menimbulkan bahaya, kerugian atau kesusahan, diancam dengan pidana denda paling banyak dua ratus dua puluh lima ribu rupiah". Muatan dari pasal tersebut memiliki kategori berupa (1) Berbeda dengan ketentuan pasal 406 KUHP pasal ini tak mensyaratkan bahwa pelaku dengan sengaja hendak menimbulkan kerugian, (2) Termasuk dalam pengertian "kerugian" adalah mengotori jalan dengan cat. ${ }^{17}$

Indonesia telah menerapkan aturan tersebut, bahkan di beberapa kota telah membuat peraturan daerah mengenai tindakan perusakan dan penghancuran barang (vandal) seperti kota Magelang, Bantul, dan Surakarta serta beberapa kota lain termasuk kabupaten Bone. Kabupaten Bone memiliki peraturan daerah yang mengatur tentang tindakan yang masuk dalam kategori merusak dan menghancurkan barang. Pemerintah membuat aturan yang memuat tentang tindakan tersebut untuk menjaga dan memelihara fasilitas umum dari tangan-tangan yang tidak bertanggung jawab. Peraturan tersebut termuat dalam peraturan daerah kabupaten Bone.

Aturan tentang perusakan (vandalisme) terdapat pada Peraturan Daerah Kabupaten Bone Nomor 13 Tahun 2016 tentang Ketertiban Umum dan Ketentraman Masyarakat, pada pasal 12 “ Setiap orang atau badan dilarang : (a) memasuki atau

16 Ismu Gunadi, Cepat dan Mudah Memahami Hukum Pidana h. 163

17 Soenarto Soerodibroto, KUHP dan KUHAP Dilengkapi Yurisprudensi Mahkamah Agung dan Hoge Raad, (Cet. XVII ; Jakarta : PT Rajagrafindo Persada, 2014) h.316 Jurnal Al-Dustur; VOLUME 2 NO 1, JUNI 2019 
berada di jalur hijau atau taman yang bukan untuk umum, kecuali untuk dinas; (b) melakukan perbuatan yang dapat merusak dan mengotori jalur hijau, taman, dan tempat umum beserta kelengkapannya; (c) bertempat tinggal atau tidur di jalur hijau, taman, dan tempat umum; (d) melakukan perbuatan berupa vandalisme terhadap fasilitas tempat umum, jalur hijau dan/atau taman beserta kelengkapannya". ${ }^{18}$

Berdasarkan Peraturan Daerah Kabupaten bone Nomor 13 Tahun 2016 pada pasal 12 ayat (4) telah disebutkan tindakan yang dilarang salah satunya adalah tindakan vandalisme. Berdasarkan penjelasan pasal tersebut disebutkan bahwa "yang dimaksud dengan vandalisme adalah kegiatan mencoret-coret atau menulis-nulis atau menggambar secara tidak beraturan disembarang tempat atau mengganti tulisan yang ada dengan hal-hal yang menyebalkan, mengosongkan halaman, atau menyisipkan lelucon yang konyol dan hal-hal yang tidak berguna lainnya". ${ }^{19}$

Peraturan Daerah Kabupaten Bone Nomor 13 tahun 2016 juga mengatur tentang tindakan lain yang sekaligus menjadi bagian dari tindakan merusak keindahan yaitu terdapat pada pasal 26 :

“dalam rangka menjaga keindahan dan kebersihan lingkungan sebagaimana dimaksud dalam pasal 25 ayat (1), semua orang atau badan dilarang melakukan perbuatan sebagai berikut : (a) mencoret-coret, menulis, melukis, menempel iklan di tembok, jembatan, halte, tiang listrik, pohon, kendaraan umum, dan sarana umum lainnya". 20

\footnotetext{
18 Lihat Peraturan Daerah Kabupaten Bone Nomor 13 Tahun 2016 tentang Ketertiban Umum dan Ketentraman Masyarakat, Pasal 12

${ }^{19}$ Lihat Peraturan Daerah Kabupaten Bone Nomor 13 Tahun 2016 tentang Ketertiban Umum dan Ketentraman Masyarakat, Penjelasan Pasal 12

${ }^{20}$ Lihat Peraturan Daerah Kabupaten Bone Nomor 13 Tahun 2016 tentang Ketertiban Umum dan Ketentraman Masyarakat, Pasal 26 
Dalam pasal tersebut menjelaskan tentang tindakan yang dikategorikan sebagai tindakan merusak keindahan.

Kota Watampone memiliki beberapa fasilitas yang diperuntukkan untuk masyarakat, namun beberapa fasilitas umum terlihat kurang terawat bahkan beberapa coretan-coretan dan kerusakan pada beberapa bangunan-bangunan seperti terdapat coretan-coretan pada dinding lapangan tenis, stadion Lapatau serta beberapa bangunan lain. Bahkan diakhir bulan agustus yang lalu terdapat aksi perusakan berupa coretan yang mengandung unsur provokatif pada beberapa fasilitas umum di kota Watampone seperti coretan menggunakan cat semprot yang bertuliskan "Bunuh Polisi" dibeberapa tempat di Kota Watampone termasuk pagar Pusat Kesehatan Masyarakat (Puskesmas) Watampone dan tempat lainnya, bukan hanya coretan saja beberapa aksi perusakan juga terjadi pada lampu-lampu taman yang terdapat di lapangan merdeka.

Berdasarkan fakta yang ditemukan bahwa fasilitas umum di kota Watampone masih rawan tindakan perusakan dan penghancuran (vandal) sehingga penulis perlu meneliti di lokasi tersebut untuk mengetahui bagaimana implementasi Peraturan Daerah Nomor 13 Tahun 2016 Tentang Ketertiban Umum dan Ketentraman Masyarakat dalam mengatasi tindakan perusakan terhadap fasilitas umum (studi di Kota Watampone).

Berdasarkan uraian latar belakang diatas, maka dapat dikemukakan rumusan masalah sebagai berikut : Bagaimana peran pemerintah dalam mengatasi tindakan perusakan terhadap fasilitas umum berdasarkan Peraturan Daerah Kabupaten Bone Nomor 13 tahun 2016 tentang Ketertiban Umum dan Ketentraman Masyarakat dan Bagaimana upaya pemerintah dan dinas terkait dalam menjaga dan

\section{TINJAUAN PUSTAKA}

Sebuah hasil penelitian hukum normatif yang bersifat preskriptif oleh Nana Jurnal Al-Dustur; VOLUME 2 NO 1, JUNI 2019 
Rosita Sari yang berjudul Efisiensi Penindakan Aksi Vandalisme Terhadap Ruang Publik di Kota Surakarta pada fakultas hukum Universitas Sebelas Maret Surakarta. Berdasarkan penelitian dan analisis yang telah dilakukan didapatkan hasil bahwa penindakan aksi vandalisme terhadap ruang publik di kota Surakarta oleh satuan polisi Pamong Praja (Satpol PP) belum terlaksana dengan baik. Hal ini dapat dilihat dari keterbatasan sarana dan prasarana pendukung kegiatan operasional mencakup jumlah personil dari Satpol PP sendiri, kurangnya peran serta dan kesadaran masyarakat mengenai penindakan aksi vandalisme, luasnya wiayah Surakarta yang kurang terjangkau oleh Satpol PP. Peraturan perundang-undangan mengenai penindakan aksi vandalisme terhadap ruang publik di kota Surakarta pun juga belum berfungsi memberikan efek jera bagi pelaku vandalisme dan sanksinya. Prosedur penindakan aksi vandalisme terhadap ruang publik di kota Surakarta pun juga kurang efisien. Hal ini dikarenakan banyaknya komponen-komponen dari tipe ideal birokrasi Max Weber yang belum terpenuhi. Visi dan misi Kantor satpol PP pun belum mendukung bagi terwujudnya penindakan aksi vandalisme terhadap ruang publik di kota Surakarta. ${ }^{21}$

Pemerintah kota Surakarta terkesan kurang serius dalam menindak aksi vandalisme atau corat-coret tersebut yang nyata-nyata membuat lingkungan menjadi kotor dan tidak enak dipandang mata. Meski telah ada keseriusan dari pemerintah kota Surakarta dengan membentuk satuan polisi pamong praja untuk mengatasi aksi vandalisme khususnya di kota Surakarta yang diatur dalam Undang-Undang Nomor 32 Tahun 2009 tentang perlindungan dan pengelolaan lingkungan hidup, Peraturan Daerah Kota Surakarta Nomor 2 Tahun 2006 tentang Pengendalian Lingkungan Hidup, Peraturan Daerah Kota Surakarta No. 29 Tahun 1981 tentang Kebersihan dan

\footnotetext{
21 Nana Rosita Sari, "Efisiensi Penindakan Aksi Vandalisme Terhadap Ruang Publik DI Kota Surakarta”. (Skripsi, Fakultas Hukum Universitas Sebelas Maret Surakarta, 2010) h. 73

Jurnal Al-Dustur; VOLUME 2 NO 1, JUNI 2019
} 
Keindahan Kota. ${ }^{22}$

Sebuah hasil penelitian deskriptif kualitatif oleh Ferry Septian Indiarto yang berjudul "Faktor-Faktor Penyebab Terjadinya Vandalisme Suporter Sepakbola di Indonesia (Studi Kasus Suporter LA Mania Lamongan)” Fakultas Ilmu Keolahragaan Universitas Negeri Surabaya. Vandalisme dalam pertandingan sepak bola semakin marak, hingga menimbulkan korban berupa harta benda atau bahkan nyawa. Diantara penonton yang suka bertindak brutal dalam pertandingan sepakbola adalah massa supporter. Mereka suka meneror, mengintimidasi, atau menyakiti siapa saja dan merusak apa saja yang dianggap sebagai penghalang. Hasil dari penelitian menyebutkan bahwa penyebab terjadinya vandalisme adalah elemen-elemen dalam persepakbolaan tidak berjalan sesuai regulasi. Kesenjangan sosial ekonomi dan rendahnya pendidikan adalah faktor di luar sepakbola juga menjadi penyebab terjadinya vandalisme. Tipisnya ikatan emosional antar supporter dan klub. Tersumbatnya saluran supporter untuk melampiaskan ketegangan emosi secara positif dan dapat diterima oleh masyarakat. ${ }^{23}$

Sebuah hasil penelitian berupa kajian teori oleh Natael Simanjuntak yang berjudul "Kemunculan Vandalisme dan Seni Grafiti di Ruang Bawah Jalan Layang” fakultas teknik Universitas Indonesia. Jalan layang adalah salah satu solusi untuk masalah persinggungan titik transportasi jalur darat. Jalan layang yang berbeban besar membutuhkan kolom yang besar pula, dan kolom yang besar membutuhkan ruang yang berukuran besar pula. Pada ruang-ruang bawah jalan layang ini kerap dijumpai vandalisme. Vandalisme menjadi sampah visual diwajah kota dan menimbulkan rasa Surakarta h. 13

22 Nana Rosita Sari, Efisiensi Penindakan Aksi Vandalisme Terhadap Ruang Publik DI Kota

${ }^{23}$ Ferry Septian Indiarto, "Faktor-Faktor Penyebab Terjadinya Vandalisme Suporter Sepakbola di Indonesia” (Studi Kasus Suporter LA Mania Lamongan”. (Skripsi, Fakultas Keolahragaan Universitas Negeri Surabaya, 2015) h. 187

Jurnal Al-Dustur; VOLUME 2 NO 1, JUNI 2019 
tidak aman bagi masyarakat kota. Namun beberapa kasus, ruang-ruang bawah jalan layang justru dimanfaatkan sebagai taman graffiti, sebuah tempat berekspresi dan menyampaikan pesan-pesan sosial yang positif bagi masyarakat kota. ${ }^{24}$

Hasil dari penelitian menyebutkan bahwa berdasarkan data perbandingan hasil analisis antara 2 studi kasus ruang bawah jalan layang Universitas Indonesia (UI) dan jalan laying Pancoran. Diruang bawah jalan layang UI terjadi tindakan vandalisme sementara diruang bawah jalan layang pancoran terjadi seni graffiti. Faktor yang menyebabkan hasil berbeda pada kedua ruang bawah jalan layang berasal dari 2 subjek yang saling terkait satu sama lain yaitu masyarakat dan otoritas yang berkepentingan serta subjek penerima Affordance..$^{25}$

Sebuah hasil penelitian menggunakan pendekatan kualitatif (qualitative research) oleh Fajar Rizki Anggono yang berjudul "Perilaku Vandalisme Pada Remaja Di Kabupaten Kulon Progo" program studi bimbingan konseling jurusan psikologi pendidikan dan bimbingan fakultas ilmu pendidikan Universitas Negeri Yogyakarta. Hasil penelitian terhadap 3 remaja pelaku vandalisme menunjukkan bahwa bentuk-bentuk vandalisme yang dilakukan adalah : (1) ideological; (2) vindicate; (3)play; (4)malicious. Faktor penyebab perilaku vandalisme: (1) teman sebaya: merasa nyaman dengan teman-temannya membuat subyek mengikuti tindakan vandalisme temannya; (2) keluarga: (a) kurangnya kasih sayang dan perhatian menyebabkan subjek melakukan vandalisme sebagai pelarian, (b) kasih sayang berlebihan menyebabkan tindakan vandalisme subjek tidak pernah dilarang; (3) media massa: subjek melakukan tindakan vandalisme karena terpengaruh film dan video game; (4) lingkungan masyarakat: sikap acuh dari lingkungan masyarakat

\footnotetext{
${ }^{24}$ Natael Simanjuntak, "Kemunculan Vandalisme dan Seni Grafiti di Ruang Bawah Jalan Layang”. (Skripsi, Fakultas Teknik Universitas Indonesia, 2012) h. 2

${ }^{25}$ Natael Simanjuntak, Kemunculan Vandalisme dan Seni Grafiti di Ruang Bawah Jalan Layang h. 60 
menyebabkan tindakan vandalisme subjek susah dihentikan. ${ }^{26}$

Berdasarkan beberapa penelitian yang telah dilakukan maka perbedaan penelitian yang akan dilakukan adalah penelitian ini berfokus pada tindakan atau perbuatan yang merusak baik merusak dalam arti merusak keindahan, merusak hingga tidak dapat dipakai lagi dan merusak dalam arti sesungguhnya yang objek perusakan pada fasilitas umum yang terdapat pada ruang publik yang ada di

\section{METODE PENELITIAN}

1. Jenis dan Pendekatan Penelitian

Penelitian ini adalah jenis penelitian lapangan. Berdasarkan dengan permasalahan yang telah dikemukakan, maka penelitian ini menggunakan pendekatan penelitian gabungan yaitu hukum normatif-empiris.

a. Penelitian hukum normatif bergerak di bidang norma yang bersifat ideal, penjelajahan pada sisi das sollen atau Normwissenschaft dari hukum. ${ }^{27}$

b. Penelitian hukum empiris terjadi pada kawasan sosiologi hukum. Sasarannya adalah Law-in-action, hukum sebagai independent maupun dependent variable, dikenal pula sebagai socio-legal research. ${ }^{28}$ Penelitian hukum sosiologis bergerak dibidang kenyataan hukum, pada aspek das sein atau Tatsachenwissenschaft (Fakta Ilmiah) dari hukum. ${ }^{29}$

Alasannya, jika pendekatan yuridis normatif saja tidak akan dapat melihat realitas yang terjadi dimasyarakat berkaitan dengan suatu aturan hukum, untuk itu diperlukan adanya pendekatan lain guna melihat hukum sebagai fenomena. tujuan

26 Fajar Rizki Anggono, "Perilaku Vandalisme Pada Remaja Di Kabupaten Kulon Progo". (Skripsi, Fakultas Ilmu Pendidikan, 2014) h.52

${ }^{27}$ Nico ngani, Metodologi Penelitian dan Penulisan Hukum, (Cet. 1; Jakarta Selatan: PT Buku Seru, 2012), h. 83

${ }^{28}$ Nico ngani, Metodologi Penelitian dan Penulisan Hukum, h. 81

${ }^{29}$ Nico ngani, Metodologi Penelitian dan Penulisan Hukum, h. 83 Jurnal Al-Dustur; VOLUME 2 NO 1, JUNI 2019 
desain penelitian deskriptif kualitatif adalah untuk menggambarkan, meringkaskan berbagai kondisi, fenomena realitas sosial yang ada di masyarakat yang menjadi obyek penelitian, dan berupaya menarik realitas itu ke permukaan sebagai suatu ciri, karakter, sifat, model, tanda, atau gambaran tentang kondisi, situasi, ataupun fenomena tertentu. $^{30}$

\section{Lokasi penelitian}

Penelitian ini berlokasi di kota Watampone, Kabupaten Bone yang berfokus pada fasilitas-fasilitas umum yang ada di kecamatan-kecamatan dalam lingkup Kota Watampone. Adapun alasan penulis memilih lokasi penelitian ini, karena penulis merasa tertarik untuk mengetahui penerapan dari peraturan daerah Kabupaten Bone dalam mengatasi tindakan perusakan dan penghancuran terhadap fasilitas umum. Sebagaimana kenyataannya, fasilitas umum yang terdapat di Kota Watampone terdapat coretan-coretan pada bangunan-bangunan umum seperti coretan yang terdapat pada Stadion Lapatau, lampu-lampu taman Lapangan Merdeka yang dirusak dan fasilitas umum yang tidak dapat digunakan karena tindakan perusakan. Hal inilah yang menjadi permasalahan utama tidak nyamannya fasilitas umum dan ruang publik bagi masyarakat. selanjutnya penulis memiliki inisiatif untuk menjadikan tempat ini sebagai objek penelitian.

3. Data dan Sumber Data

Data dan Sumber data dalam penelitian adalah subjek dari mana data diperoleh. ${ }^{31}$ Adapun yang menjadi sumber data dalam penelitian ini adalah sebagai berikut:

\footnotetext{
${ }^{30}$ Burhan Mungim, Peneltian Kualitatif: Komunikasi, Ekonomi, Kebijakan Publik, dan Ilmu Sosial Lainny, (Jakarta: Prenada Media Group, 2008), h. 68.

${ }^{31}$ Suharsimi Arikunto, Prosedur Penelitian Suatu Pendekatan Praktek, (Cet. XII; Jakarta: PT Rineka Cipta, 2002), h. 107. 
a. Data primer merupakan data yang diperoleh langsung dari sumber pertama. ${ }^{32}$ Data primer adalah data yang diperoleh secara langsung di lapangan yang merupakan data mentah ( $r a w$ data) yang masih memerlukan pengelolaan lebih lanjut. ${ }^{33}$ Data yang diperoleh langsung dari pemerintah tiap kecamatan terkait tindakan vandalisme terhadap fasilitas umum di Kota Watampone.

b. Data sekunder mencakup dokumen-dokumen resmi, buku-buku, hasil penelitian yang berwujud laporan. ${ }^{34}$ Berbeda dengan data primer yang belum diolah, maka data sekunder adalah data yang telah diolah. ${ }^{35}$

\section{Instrumen Penelitian}

Intrumen penelitian merupakan alat yang digunakan dalam pengumpulan data. Dalam penelitian ini akan menggunakan alat yaitu daftar pertanyaan, recorder dari handphone dibantu alat tulis lainnya, kemudian dibuatkan transkripnya dengan mengubah hasil wawancara tersebut dari bentuk rekaman menjadi bentuk tertulis. ${ }^{36}$

\section{Teknik Pengumpulan Data}

Teknik yang digunakan untuk mengumpulkan data dalam penelitian ini dengan menggunakan beberapa teknik, yaitu :

a. Wawancara secara mendalam adalah proses memperoleh keterangan untuk tujuan penelitian dengan cara Tanya jawab sambil bertatap muka antara pewawancara dan informan atau orang yang diwawancarai dengan atau tanpa menggunakan pedoman (guide) wawancara, di mana pewawancara

\footnotetext{
${ }^{32}$ Amiruddin dan Zainal Asikin, Pengantar Metode Penelitian Hukum, (Cet.1; Jakarta: PT. Grafindo Persada, 2004), h. 30

${ }^{33}$ Syahruddin Nawi, Penelitian Hukum Normatif Versus Penelitian Hukum Empiris, (Cet. II; Makassar : PT. Umitoha Ukhuwah Grafika, 2014)) h.29

${ }^{34}$ Amiruddin dan Zainal Asikin, Pengantar Metode Penelitian Hukum h. 30

35 Syahruddin Nawi, Penelitian Hukum Normatif Versus Penelitian Hukum Empiris h.29

${ }^{36}$ Muhammad Teguh, Metodologi Penelitian Ekonomi Teori dan Aplikasi, (Ed.1-3;Jakarta: PT.RajaGrafindo Persada, 2005), h. 136-137. 
34 | Implementasi Peraturan Daerah Nomor 13 Tahun 2016

dan informan terlibat dalam kehidupan sosial relatif lama. ${ }^{37}$ Beberapa pihak yang diwawancarai meliputi beberapa camat yang ada di Kota Watampone, Dinas Pekerjaan Umum dan Tata Ruang Kabupaten Bone dan Satuan Polisi Pamong Praja (SATPOL PP) Kabupaten Bone.

b. Observasi atau pengamatan adalah kegiatan keseharian manusia dengan menggunakan pancaindra mata sebagai alat bantu utamanya. Karena itu observasi adalah kemampuan seseorang untuk menggunakan pengamatannya melalui hasil kerja pancaindra mata serta dibantu dengan panca indra lainnya. ${ }^{38}$

c. Catatan Lapangan merupakan coretan seperlunya yang sangat dipersingkat, berisi kata-kata inti, frase, pokok-pokok isi pembicaraan, atau pengamatan, mungkin gambar, sketsa, sosiogram, diagram, dan lain-lain. Proses itu dilakukan setiap kali selesai mengadakan pengamatan atau wawancara. ${ }^{39}$

6. Teknik Analisis Data

Dalam menganalisis data, penulis menggunakan analisis data secara kualitatif, analisis data kualitatif adalah penelitian yang berupaya menganalisis kehidupan sosial menggambarkan dunia sosial dari sudut pandang atau interpretasi individu (informan) dalam latar alamia. Dengan kata lain penelitian kualitatif berupaya menjelaskan bagaimana seorang individu, menggambarkan, atau memaknai dunia sosialnya. Analisis kualitatif dengan tahapan sebagai berikut:

a. Pengumpulan data lapangan yakni dengan mengumpulkan data yang ditemukan dilapangan yang merupakan data kasar.

37 Burhan Bungi, Penelitian Kualitatif Komunikasi, Ekonomi, Kebijakan Publik, dan Ilmu Sosial Lainnya h. 111

38 Burhan Bungi, Penelitian Kualitatif Komunikasi, Ekonomi, Kebijakan Publik, dan Ilmu Sosial Lainnya h. 118

39 Lexy J. Moleong, Metodologi Penelitian Kualitatif, Ed. Revisi, (Cet. 22; Bandung: PT Remaja Rosdakarya, 2004), h. 153

Jurnal Al-Dustur; VOLUME 2 NO 1, JUNI 2019 
b. Reduksi data adalah proses memilih atau menyederhanakan, mengabstraksikan dan mentransformasikan data kasar yang baru dari lapangan.

c. Penyajian data merupakan sekumpulan informasi yang tersusun secara sistematis yang kemungkinan adanya penarikan kesimpulan. ${ }^{40}$

\section{HASIL PENELITIAN DAN PEMBAHASAN}

\section{Peran Pemerintah dalam Mengatasi Tindakan Perusakan Terhadap Fasilitas Umum}

Fasilitas umum sebagai bagian dari proses pembangunan untuk meningkatkan ekonomi, sosial, politik hingga peningkatan mutu sumberdaya manusia. Namun di era globalisasi, kebebasan menyampaikan pendapat sebagai bentuk ekpresi mengakibatkan penyampaian aspirasi tidak berdasarkan aturan. Beberapa masyarakat menyampaikan aspirasi mereka melalui tindakan perusakan fasilitas umum dengan mencoret menggunakan cat semprot hingga perbuatan yang merusak lainnya. Di pertengahan bulan agustus di Kota Watampone telah terjadi tindakan perusakan yang berupa mencoret beberapa fasiitas umum di Kota Watampone, perbuatan tersebut sebagai bentuk penyampaian aspirasi namun tidak berdasarkan aturan.

Pemerintah diharapkan melakukan penindakan yang tegas terhadap para pelaku pengrusakan fasilitas umum terutama pada fasilitas umum yang dianggap sebagai fasilitas vital di daerah seperti taman kota, stadion, halte, jalan, puskesmas, sekolah dan beberapa fasilitas umum lainnya. Meski beberapa masyarakat menganggap bahwa kerusakan yang diakibatkan tidak terlalu parah, namun jika terus dibiarkan akan menimbulkan kerusakan yang lebih besar lagi dan pelakunya akan menjadikan

40 Muhammad Tholchah Hasan dkk, Metode Penelitian Kualitatif Tinjauan Teoritis dan Praktis, (Cet. 3; Surabaya: Visipress Media,2009), h. 183 
kegiatan tersebut sebagai tindakan yang dianggap biasa jika tidak segera ditindak. ${ }^{41}$

Pemerintah memiliki satuan kerja perangkat daerah yang memiliki tugas dalam penegakan Peraturan Daerah (PERDA) khususnya pada ketertiban dan ketentraman umum, yaitu Satuan Polisi Pamong Praja. Munurut Peraturan Pemerintah Nomor 6 Tahun 2010 Tentang Satuan Polisi Pamong Praja, menjelaskan bahwa Satuan Polisi Pamong Praja yang selanjutnya disingkat Satpol PP adalah bagian dari perangkat daerah dalam penegakan perda dan penyelenggaraan ketertiban umum dan ketentraman masyarakat. Dalam undang-undang tersebut juga dijelaskan tentang pembentukan, kedudukan, tugas dan fungsi dari satpol PP adalah untuk membantu kepala daerah dalam menegakkan perda dan penyelenggaraan ketertiban umum dan ketentraman masyarakat, disetiap provinsi dan kabupaten/kota dibentuk Satpol PP.

Kota Watampone sebagai ibukota Kabupaten Bone memiliki fasilitas umum yang nikmati oleh seluruh lapisan masyarakat. Namun adapula masyarakat yang tidak menjaga fasilitas umum yang telah dibangun oleh pemerintah daerah Kabupaten Bone sehingga pemerintah Kabupaten Bone membuat aturan tentang perlunya menjaga fasilitas umum dan menetapkan beberapa aturan tentang tindakan perusakan seperti pada pasal 12 dan 26 Peraturan Daerah Kabupaten Bone Nomor 13 Tahun 2016 Tentang Ketertiban Umum dan Ketentraman Masyarakat. Dalam pasal tersebut diatur tentang larangan tindakan Vandalisme (perbuatan yang mencoret-coret dinding) serta larangan lain yang menyangkut fasilitas umum dan ruang terbuka. Pasal tersebut juga memberikan sanksi yang tegas dari pelaku perusakan fasilitas umum yaitu berupa sanksi pidana.

Berdasarkan data tentang perusakan yang terjadi di Kabupaten bone yang terdapat pada Badan Pusat Statisti Kabupaten Bone yang bersumber dari data Polres Bone yaitu ditahun 2016 sebanyak 18 kasus yang dilaporkan dan 11 kasus yang dapat

\footnotetext{
${ }^{41}$ Andi Ikrar, Sekertaris Camat Tanete Riattang Timur, Wawancara, di Watampone, 01 Januari
} 2018 
diselesaikan. ${ }^{42}$ Pada tahun 2014 sebanyak 5 kasus yang dilaporkan dan hanya 2 kasus yang dapat diselesaikan. ${ }^{43}$ Pada tahun 2012 terdapat 15 kasus yang dilaporkan dan hanya 10 yang dapat diselesaikan. ${ }^{44}$

Satuan Polisi Pamong Praja (Satpol PP) Kabupaten Bone sebelum melaksanakan tugasnya terlebih dahulu melakukan sosialisasi terhadap perda yang harus ditaati oleh masyarakat. Perda yang telah disahkan harus disosialisasikan kepada masyarakat agar masyarakat mengetahui adanya aturan yang mengikat. Satpol PP melakukan penindakan terhadap para pelanggar perda baik yang melakukan pelanggaran yang sanksinya berupa sanksi administratif hingga sanksi pidana. ${ }^{45}$

Pelaku yang kedapatan melanggar perda terlebih dahulu akan diberikan pembinaan atau penyuluhan. Namun jika pelaku yang melanggar perda yang diancam dengan sanksi pidana maka akan diserahkan kepada Kepolisian Republik Indonesia. Hal ini termuat dalam Peraturan Pemerintah Nomor 6 Tahun 2010 Tentang Satuan Polisi Pamong Praja pada pasal 8 huruf d bahwa polisi pamong praja wajib melaporkan kepada Kepolisian Negara Republik Indonesia atas ditemukannya atau patut diduga adanya tindak pidana. Dalam pasal lain satpol PP juga berhak melakukan kerja sama dengan kepolisian atau lembaga lainnya.

Kendala yang dihadapi satpol PP Kabupaten Bone berupa kurangnya jumlah personil sehingga penegakan perda sulit untuk dilaksanakan, kemudian dari keseluruhan personil kebanyakan dari mereka tidak mengetahui tentang perda khususnya perda tentang ketertiban umum dan ketentraman masyarakat. Selain itu hal yang menjadi kendala utama adalah pada saat peraturan daerah dibuat pihak dari satpol

${ }^{42}$ Data Badan Pusan Statistik Kabupaten Bone, Kabupaten Bone dalam Angka tahun 2017, h. 5

${ }^{43}$ Data Badan Pusan Statistik Kabupaten Bone, Kabupaten Bone dalam Angka tahun 2015, h. 111

${ }^{44}$ Data Badan Pusan Statistik Kabupaten Bone, Kabupaten Bone dalam Angka tahun 2015, h. 110

${ }^{45}$ A. Baharuddin, KABID TRANTIB Satpol PP Kab. Bone, Wawancara, di Watampone, 12 Desember 2017

Jurnal Al-Dustur; VOLUME 2 NO 1, JUNI 2019 
PP tidak disertakan dalam pembuatan peraturan daerah. Kendala lain yang dihadapi satpol PP juga berupa tidak adanya koordinasi antar SKPD terkait sehingga hal ini menyulitkan pihak satpol PP. koordinasi antar lebaga lain sangat diperlukan untuk upaya pembinaan dan penyuluhan tentang perda. Kerja sama antar lembaga sangat diperlukan demi menegakkan dan menjaga ketertiban dan ketentraman namun hal ini tidak sesuai dengan apa yang diharapkan oleh satpol PP.

Saat melaksanakan tugas satuan polisi pamong praja juga harus didukung oleh sarana dan prasarana operasional saat bertugas. Namun, hal ini tidak sejalan dengan apa yang diharapkan. Kurangnya sarana dan prasarana pendukung seperti kendaraan operasional ditambah pula dengan kurangnya jumlah personil satpol PP mengakibatkan penegakan perda kurang maksimal. Dengan berbagai kendala, tugas dan fungsi satpol PP harus tetap dilaksanakan demi penegakan perda maka kepala ketentraman dan ketertiban satpol PP Kabupaten Bone melakukan upaya penjagaan wilayah yang dianggap rawan.

\section{a) Tujuan Pembangunan Daerah}

Para ahli cenderung berbeda dalam memberi makna dan mendefenisikan pembangunan. Ini sangat tergantung pada dimensi mana yang ingin ditekankan. Jika dirunut berbagai pemikiran yang berkembang dalam mendefenisikan pembangunan, maka Nampak bahwa pembangunan bukanlah konsep yang statis, tetapi ia senantiasa berkembang sesuai dengan konteks waktu yang melingkupinya. Dalam hal ini, Adrian Leftwich, salah seorang penulis politik pembangunan, mengemukakan bahwa pemahaman pembangunan yang paling umum dapat dikategorikan ke dalam Sembilan pendekatan pokok, yakni pembangunan dilihat sebagai kemajuan historis (development as historical progress), pembangunan sebagai eksploitasi sumber daya alam (development as the exploitation of natural resources), pembangunan sebagai promosi kemajuan ekonomi, dan (kadang kala) social, dan politik yang direncanakan (development as the promotion of planned of economic, and (sometimes) social and political advancement); pembangunan sebagai suatu kondisi (development as a 
condition); pembangunan sebagai suatu proses (development as a process); pembangunan sebagai perubahan struktural (development as structural change); pembangunan sebagai modernisasi (development as a modernization); dan pembangunan sebagai suatu peningkatan kekuatan produksi (development as an increase in the forces of production). Diantara pendekatan tersebut, pertumbuhan, modernisasi, dan perubahan struktur telah menjadi ortodoksi dominan yang menyangkut makna dan tujuan pembangunan pada tahun-tahun segera setelah Perang Dunia Kedua. ${ }^{46}$

Pembangunan daerah dilakukan demi meningkatkan kemajuan ekonomi, social, politik serta meningkatkan kesejahteraan masyarakat. pembangunan daerah bukan hanya mengutamakan pembangunan sumber daya manusianya namun juga mempertimbangkan dari segi pembangunan fisik. Pembangunan fisik yang dimaksud adalah pembangunan infrastruktur publik atau fasilitas umum yang digunakan oleh masyarakat demi terciptanya masyarakat yang sejahtera. Pembangunan fasilitas umum bertujuan pula untuk membantu meningkatkan pembangunan disektor lain seperti pembangunan dari segi ekonomi, social, dan budaya. Beberapa dampak positif yang dapat di rasakan dari pembangunan fasilitas umum seperti pembangunan taman kota atau ruang terbuka hijau sebagai sarana rekreasi bagi masyarakat, pembangunan fasilitas olahraga (gedung olahraga) sebagai bagian dari peningatan kesejahteraan dan sarana yang diperuntukkan bagi masyarakat secara umum.

\section{Peran Pemerintah dalam Pembangunan Fasilitas Umum}

Pemerintah selaku pihak yang memiliki wewenang dalam menampung aspirasi masyarakat. Masyarakat akan menyampaikan aspirasinya melalui perangkat desa atau kelurahan yang akan ditampung dan akan dibahas dalam Musyawarah Rencana pembangunan (Musrenbang) desa/kelurahan, setelah itu hasil dari musyawarah ditingkat Desa/Kelurahan selanjutnya akan dibahas dalam Musyawarah Rencana

46 Budi Winarno, Etika pembangunan, h. 237

Jurnal Al-Dustur; VOLUME 2 NO 1, JUNI 2019 
Pembangunan (Musrenbang) tingkat Kecamatan, dalam musrenbang kecamatan akan dibacakan juga usulan sebelumnya yang telah direalisasikan di tahun tersebut. Melalui Musrenbang kecamatan, hasil musrenbang di setiap kelurahan akan dibahas dan selanjutnya akan diteruskan dan dibahas dalam musyrenbang ditingkat kabupaten. Dalam musyrenbang kabupaten akan dihadiri oleh anggota Dewan Perwakilan Rakyat Daerah (DPRD) Provinsi dan Badan Perencanaan Pembangunan Daerah (BAPPEDA) Provinsi, kemudian hasil dari pembahasan musrenbang ditingkat kabupaten akan diteruskan dalam musrenbang provinsi hingga musrenbang nasional. ${ }^{47}$

Musyawarah perencanaan pembangunan dilakukan guna menampung aspirasi atau keluhan, rencana pembangunan hingga perawatan dan perbaikan sarana dan prasarana umum. Usulan-usulan pembangunan dari masyarakat baik usulan berupa pembangunan fasilitas umum maupun pembangunan non-fisik seperti pemberdayaan masyarakat dan lain-lain harus didasarkan pada skala prioritas. ${ }^{48}$ Rencana pembangunan dan perawatan fasilitas umum harus didasarkan pada skala prioritas seperti penting mendesak, penting tidak mendesak, mendesak tidak penting dan tidak mendesak dan tidak penting sebagai bahan pertimbangan. Musyawarah perencanaan pembangunan dilakukan sekali dalam setahun guna melaksanakan rencana pembangunan dalam setahun yang didasarkan baik pada Rencana Pembangunan Jangka Panjang Nasional (RPJPN) maupun Rencana Pembangunan Jangka Menengah Nasional (RPJMN). kabupaten Bone memiliki Rencana Pembangunan Jangka Menengah Daerah (RPJMD) yang dijadikan dasar dalam pembangunan yang akan dilakukan ditingkat kecamatan hingga desa/kelurahan.

Jadi, ringkasnya jika pembangunan adalah isu manajemen dan menejemen adalah masalah prioritas maka pertanyaannya, apakah prioritas itu ? jawabannya Desember 2017

47 A. Ikbar Baso, Sekertaris Camat Tanete Riattang Barat, Wawancara, di Watampone, 21

48 A. Kumala Dewi Salahuddin, Sekertaris Camat Tanete Riattang, Wawancara, di Watampone, 29 November 2017 
sederhana, bahwa kita harus meletakkan "waktu" sebagai sumber daya paling penting karena tidak dapat dibeli dan ditarik kembali. Seperti halnya nasihat untuk para eksekutif yang ingin menjadi efektif, kelolalah waktu dengan sebaik-baiknya. Ini adalah kunci penentuan prioritas. Tabel berikut ini dapat membantu untuk menentukan prioritas.

Pembangunan berarti Kepala Pemerintahan dan / atau Kepala Negara harus mampu memilih prioritas; mana yang kuadran I, mana kuadran II, mana kuadran III, dan mana kuadran IV. Presiden atau perdana menteri sebagai pimpinan puncak lembaga eksekutif mempunyai kewajiban merumuskan prioritas pembangunan, baru kemudian menyusun tat-urutan manajemen, mulai planning hingga controlling; atau dalam sekuensi perencanaan hingga kegiatan; atau dari visi hingga implementasi. ${ }^{49}$

Barangkali, matriks ini tidak begitu menyenangkan, karena dengan penyusunan prioritas seperti ini, maka otomatis sektor yang menjadi prioritas adalah kuadran I dan kuadran II. Prioritas ini mempunyai pengaruh kepada anggaran dalam arti lembaga pemerintah yang berada di luar kedua kuadran tersebut harus ikhlas mengalah. Ini menjadi permasalahan, karena biasanya kepentingan sektoral lah yang menjadi penentu. Pasti terjadi proses tarik menarik anggaran antar sektor. Di sini peran Presiden sangat menentukan. ${ }^{50}$

Pemerintah memiliki peran dalam pembangunan baik pembangunan fisik maupun non-fisik. Masyarakat sadar bahwa mereka membutuhkan fasilitas yang dapat memudahkan pekerjaan mereka serta dapat diakses oleh masyarakat secara umum. Maka dari itu masyarakat akan menyampaikan usulan pembangunan fasilitas umum

49 Rian Nugroho Dwijowijoto, Reinventing Pembangunan Menata Paradigma Pembangunan untuk Membangun Indonesia Baru dengan Keunggulan Global, h. 234

${ }^{50}$ Rian Nugroho Dwijowijoto, Reinventing Pembangunan Menata Paradigma Pembangunan untuk Membangun Indonesia Baru dengan Keunggulan Global, h. 235 
kepada pemerintah di desa/kelurahan yang nantinya akan diteruskan hingga ke pemerintah daerah yang selanjutnya akan diteruskan melalui Satuan Kerja Perangkat Daerah (SKPD) terkait. Ketika pembangunan fasilitas umum telah selesai maka peran pemerintah dan masyarakat sangat penting dalam proses menjaga dan merawat fasilitas umum. ${ }^{51}$

Fasilitas umum dibangun guna mempermudah pekerjaan masyarakat serta memberikan keyamanan di masyarakat. Pembangunan fasilitas umum diwilayah ibukota kabupaten lebih diprioritaskan sebagai pusat pemerintahan di kabupaten. Pembangunan fasilitas umum bertujuan untuk meningkatkan pembangunan di bidang sosial, ekonomi, politik maupun sumberdaya manusianya.

\section{Perawatan dan Pemeliharaan Fasilitas Umum}

Fasilitas umum menjadi bagian yang tak terpisahkan dalam kehidupan masyarakat, mulai dari jalan, taman kota dan ruang terbuka hijau, halte, taman-taman, stadion, tugu hingga sarana dan prasarana sosial seperti sekolah, rumah sakit, dan pusat kesehatan masyarakat (Puskesmas). Pemerintah selaku pihak yang membangun dan merawat fasilitas umum tersebut telah melakukan tindakan dan upaya terbaik demi meningkatkan kenyamanan dan kemudahan bagi masyarakat. Perawatan dan pemeliharaan fasilitas umum dilakukan melalui Satuan Kerja Perangkat Daerah (SKPD) terkait dalam rencana pembangunan dan perbaikan tiap tahunnya yang termuat dalam hasil musrenbang.

Pemerintah di tingkat kecamatan berupaya untuk menjaga fasilitas umum yang ada di kecamatannya melalui kerjasama dengan satuan kerja perangkat daerah terkait karena stiap SKPD memiliki tugas dan program kerja tersendiri yang juga berkaitan dengan perbaikan dan perawatan fasilitas yang menjadi kewenangannya. Pemerintah di desa/kelurahan hingga kecamatan hanya sebagai penyambung aspirasi masyarakat

${ }^{51}$ A. Kumala Dewi Salahuddin, Sekertaris Camat Tanete Riattang, Wawancara, di Watampone, 29 November 2017 
untuk diteruskan ke pemerintah kabupaten dan untuk selanjutnya akan dilaksanakan berdasarkan tugas dan wewenang SKPD yang bersangkutan.

Konsep perencanaan pembangunan Bottom-Up Planning.

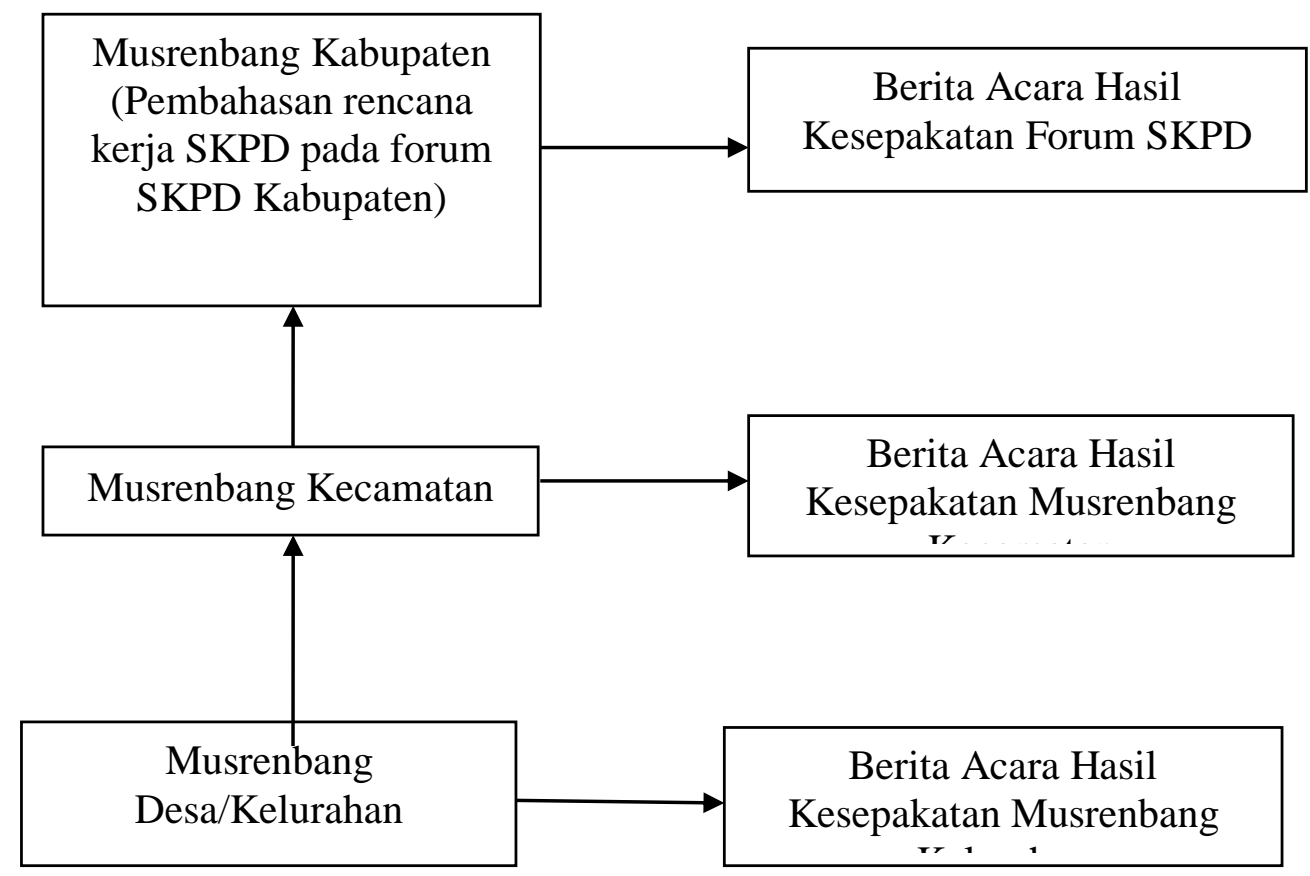

Alur perencanaan dan perawatan fasilitas umum memiliki alur yang sama dengan perencanaan pembangunan fasilitas umum. Dalam hal ini pemerintah telah melakukan upaya terbaik untuk peningkatan kualitas fasilitas umum demi kepentingan masyarakat. Namun masyarakat juga harus berperan dalam menjaga dan memelihara fasilitas umum yang telah dibangun oleh pemerintah. Fasilitas umum yang dihibahkan memiliki perbedaan dari segi perawatan dan pemeliharaannya, untuk fasilitas umum yang dihibahkan pemerintah memberikan sepenuhnya kepada masyarakat.

Pihak lain yang juga memiliki tugas untuk melakukan perbaikan fasilitas umum dan tata kota adalah dinas pekerjaan umum dan tata ruang. Dinas pekerjaan umum dan tata ruang akan melakukan perbaikan apabila terdapat aduan dari masyarakat tentang 
adanya fasilitas umum yang rusak. Pelaporan atau aduan dari masyarakat dapat dilakukan secara perseorangan maupun melalui pemerintah didesa / kelurahan. Kemudian akan dibentuk tim yang bertugas untuk meninjau lokasi untuk melihat seberapa besar dana yang dibutuhkan untuk perbaikan. ${ }^{52}$

Proses pelaksanaan perbaikan fasilitas umum dilakukan secara bertahap dan dilaksanaka setiap tahunnya menggunakan Anggaran Pendapatan Belanja Daerah (APBD) sehingga alurnya tetap melalui musrenbang kabupaten. Melalui musre kabupaten, dinas Pekerjaan Umum (PU) dan Tata Ruang akan diberikan ....... berdasarkan kewenangannya. Pelaksanaan pembangunan maupun perbaikan dilakukan dengan prosedur tender. ${ }^{53}$

\section{PENUTUP}

Setelah penelti melakukan penelitian yang berua penelitian lapangan (field Reserch) dengan judul "Implementasi Peraturan Daerah Nomor 13 Tahun 2016 Tentang Ketertiban Umum dan Ketentraman Masyarakat dalam Mengatasi Tindakan Perusakan Terhadap Fasilitas Umum di Kota Watampone", maka peneliti dapat memberikan kesimpulan sebagai berikut:

1. Pemerintah memiliki Satuan Kerja Perangkat Daerah (SKPD) yang berperan dalam penegakan perda yaitu Satpol PP. melalui satuan polisi pamong praja penegakan perda akan dilaksanakan utamanya yang berkaitan dengan ketertiban umum dan ketentraman masyarakat. Fasilitas umum yang ada dikabupaten bone perlu dijaga sehingga peran satpol PP sangat dibutuhkan guna mengatasi tindakan perusakan terhadap fasilitas umu yang ada di Kota Watampone. Satuan Polisi Pamong Praja (SATPOL PP) dalam

\footnotetext{
52 Junaedhy, Kasi Pemanfaatan Ruang, Wawancara, di Watampone, 12 Desember 2017

53 Junaedhy, Kasi Pemanfaatan Ruang, Wawancara, di Watampone, 12 Desember 2017 Jurnal Al-Dustur; VOLUME 2 NO 1, JUNI 2019
} 
Peraturan Pemerintah Nomor 6 Tahun 2010 telah memiliki tugas dan wewenang tersendiri dalam penegakan perda, contohnya jika terdapat perda yang hukumannya berupa hukuman pidana maka dalam pasal 8 huruf $d$ menyebutkan bahwa Polisi Pamong Praja wajib melaporkan kepada kepolisian Negara Republik Indonesia atas ditemukannya atau patut diduga adanya tindak pidana. Dalam pasal lain satpol PP juga berhak melakukan kerjasama dengan kepolisian atau lembaga lain. Kasus perusakan masuk kedalam kategori tindak pidana yang dimasukkan kedalam perda Kabupaten Bone sehingga peran SATPOL PP sangat dibutuhkan serta perlu adanya kerjasama dengan kepolisian sector Bone. Namun satpol PP memiliki kendala dalam penegakan perda sehingga dalam menegakkan perda utamanya tentang tindakan perusakan fasilitas umum kurang maksimal. Kendala yang dihadapi mulai dari kurangnya partisipasi masyarakat dalam pelaporan, kurangnya sarana operasional, kurangnya personil dan kurangnya pengetahuan personil tentang perda, kurangnya koordinasi antar SKPD, hingga kurang pro-aktifnya aparat pemerintah yang ada dikelurahan dalam menyampaikan keluhan masyarakat dari segi ketertiban dan ketentraman umum.

2. Upaya pemerintah dalam menjaga dan merawat fasilitas umum diakukan melalui perencanaan pembanguan yang dilaksanakan tiap tahunnya. Melalui musyawarah rencana pembangunan (musrenbang) pemerintah akan merealisasikan apa yang dibutuhkan masyarakat berdasarkan skala prioritas. Melalui musrenbang baik di tingkat desa/kelurahan hingga tingkat kabupaten, pembangunan dan perawatan fasilitas umum terus direncanakan karena ini menyangkut kesejahteraan masyarakat. Selain pemerintah, masyarakat diharapkan untuk pro-aktif dalam menjaga dan melaporkan apabila ada kerusakan pada fasilitas umum sehingga nantinya akan dimasukkan dalam musrenbang untuk selanjutnya dilakukan perbaikan. 


\section{REFERENSI}

A. Muh. Ali, Bone Selayang Pandang, t.Cet; Bone; diperbanyak oleh PEMDA TK II Bone, 1969.

Anggono, Fajar Rizki. "Perilaku Vandalisme Pada Remaja Di Kabupaten Kulon Progo". Skripsi, Fakultas Ilmu Pendidikan, 2014.

Arikunto, Suharsimi. Prosedur Penelitian Suatu Pendekatan Praktek, Cet. XII; Jakarta: PT Rineka Cipta, 2002.

Asikin,Amiruddin dan Zainal. Pengantar Metode Penelitian Hukum, .Cet.1; Jakarta: PT. Grafindo Persada, 2004.

Asteryna Anandita, "Pelaksanaan Pembangunan Sarana Prasarana Lingkungan Sebagai Wujud Program Pemberdayaan Masyarakat Di Kelurahan Dinoyo Kota Malang" Jurnal, Malang.

Budi Winarno, Etika pembangunan, Cet I; Jakarta: PT Buku Seru, 2013.

Bungi, Burhan. Penelitian Kualitatif Komunikasi, Ekonomi, Kebijakan Publik, da Ilmu Sosial Lainnya. Jakarta: Prenada Media Group, 2008.

Data Badan Pusan Statistik Kabupaten Bone, Kabupaten Bone dalam Angka tahun 2017.

Dwijowijoto, Rian Nugroho. Reinventing Pembangunan Menata Paradigma Pembangunan untuk Membangun Indonesia Baru dengan Keunggulan Global, t.Cet; Jakarta : PT. Elex Media Komputerindo, 2003.

Dwithia, Zora Febriena. Makna “Fasilitas Umum” Dalam Pengdaan Tanah Untuk Kepentingan Umum Dalam Mewujudkan Kepastian Hukum Bagi Masyarakat, Jurnal, Fakultas Hukum, Universitas Brawijaya Malang, 2014.

Ginting, Wahyu Adi Putra. lidahibu.com/2012/04/07/vandal, 11 Agustus 2017

Gunadi, Ismu. Cepat dan Mudah Memahami Hukum Pidana, Cet. Ke-2 ; Jakarta : PT Fajar Interpratama Mandiri, 2015.

Hasan Muhammad Tholchah, dkk, Metode Penelitian Kualitatif Tinjauan Teoritis dan Praktis, Cet. 3; Surabaya: Visipress Media,2009.

Indiarto, Ferry Septian. "Faktor-Faktor Penyebab Terjadinya Vandalisme Suporter Sepakbola di Indonesia (Studi Kasus Suporter LA Mania Lamongan". Skripsi, Fakultas Keolahragaan Universitas Negeri Surabaya, 2015.

Jeddawi, Murtir. Hukum Pemerintahan Daerah Cet. 1 ; Yogyakarta : UII Press Yogyakarta, 2006.

Labolo, Muhadam. Memahami Ilmu Pemerintahan, t.Cet; ed. 1; Jakarta: PT Raja Grafindo Persada, 2006.

Lihat Republik Indonesia, Peraturan Daerah Kabupaten Bone Nomor 13 Tahun 2016 tentang Ketertiban Umum dan Ketentraman Masyarakat, Pasal 26 
Moleong, Lexy J. Metodologi Penelitian Kualitatif, Ed. Revisi, Cet. 22; Bandung: PT Remaja Rosdakarya, 2004.

Nawawi, Syahruddin. Penelitian Hukum Normatif Versus Penelitian Hukum Normatif, Cet. 2; PT Umitoha Ukhuwah Grafika, 2014.

Ngani, Nico. Metodologi Penelitian dan Penulisan Hukum, Cet. 1; Jakarta Selatan: PT Buku Seru, 2012.

Republik Indonesia, Peraturan Daerah Kabupaten Bone Nomor 13 Tahun 2016, Tentang Ketertiban Umum dan Ketentraman Masyarakat.

Republik Indonesia, Peraturan Daerah Kabupaten Bone Nomor 13 Tahun 2016 tentang Ketertiban Umum dan Ketentraman Masyarakat, Pasal 12

Sari, Nana Rosita. "Efisiensi Penindakan Aksi Vandalisme Terhadap Ruang Publik DI Kota Surakarta". Skripsi, Fakultas Hukum Universitas Sebelas Maret Surakarta, 2010.

Shihab, M. Quraish, Tafsir Al-Mishbah, Cet. 5 ; Jakarta : Penerbit Lentera Hati, 2006.

Shihab, M. Quraish. Tafsir Al-Mishbah, Cet. 4 ; Jakarta : Penerbit Lentera Hati, 2005.

Simanjuntak, Natael. "Kemunculan Vandalisme dan Seni Grafiti di Ruang Bawah Jalan Layang”. Skripsi, Fakultas Teknik Universitas Indonesia, 2012.

Sitanggang, Perencanaan Pembangunan, Cet. I; Jakarta: PT Penebar Swadaya, 1999.

Sitanggang, Perencanaan Pembangunan, Cet. I; Jakarta: PT Penebar Swadaya, 1999.

Soerodibroto, Soenarto. KUHP dan KUHAP Dilengkapi Yurisprudensi Mahkamah Agung dan Hoge Raad, Cet. XVII ; Jakarta : PT Rajagrafindo Persada, 2014.

Sudarsono, Etika Islam Tentang Kenakalan Remaja Cet. IV; Jakarta : PT Rineka Cipta, 2005.

Teguh, Muhammad. Metodologi Penelitian Ekonomi Teori dan Aplikasi, Ed.13;Jakarta: PT.RajaGrafindo Persada, 2005.

Tim Reality, Kamus Terbaru Bahasa Indonesia, Cet. I ; Surabaya : Reality Publisher, 2008.

Usman, Nurdin. Konteks Implementasi Berbasis Kurikulum, T.Cet; Jakarta: PT. Raja Grafindo Persada,2002.

Wahid, Yunus. Pengantar Hukum Tata Ruang, Cet. I ; Jakarta: PT Fajar Interpratama Mandiri, 2014.

Zora Febriena Dwithia, Makna "Fasilitas Umum" Dalam Pengdaan Tanah Untuk Kepentingan Umum Dalam Mewujudkan Kepastian Hukum Bagi Masyarakat, Jurnal, Fakultas Hukum, Universitas Brawijaya Malang, 2014. 